\title{
Development and agronomic performance of common bean lines simultaneously resistant to anthracnose, angular leaf spot and rust
}

\author{
V. A. Ragagnin ${ }^{1}$, T. L. P. O. de Souza ${ }^{1}$, D. A. Sanglard ${ }^{1}$, K. M. A. Arruda ${ }^{1}, M \cdot$ R. Costa ${ }^{1}$, \\ A. L. Alzate-Marin ${ }^{2}$, J. E. de S. Carneiro ${ }^{3}$, M. A. Moreira ${ }^{1,4}$ and E. G. de Barros ${ }^{1,5}$ \\ ${ }^{1}$ Instituto de Biotecnologia Aplicada à Agropecuária (BIOAGRO), Universidade Federal de Viçosa (UFV), 36570-000 Viçosa, \\ Minas Gerais, Brazil; ${ }^{2}$ Departamento de Genética, Laboratório de Genética Vegetal, Universidade de São Paulo, Av. \\ Bandeirantes 3900, 14049-900 Ribeirão Preto, São Paulo, Brazil; ${ }^{3}$ Departamento de Fitotecnia, UFV, 36570-000 Viçosa, Minas \\ Gerais, Brazil; ${ }^{4}$ Departamento de Bioquímica e Biologia Molecular, UFV, 36570-000 Viçosa, Minas Gerais, Brazil; \\ ${ }^{5}$ Corresponding author, E-mail: ebarros@ufv.br \\ With 2 figures and 4 tables
}

Received January 24, 2008/Accepted June 16, 2008

Communicated by $S$. Abbo

\begin{abstract}
The common bean is affected by several pathogens that can cause severe yield losses. Here we report the introgression of resistance genes to anthracnose, angular leaf spot and rust in the 'carioca-type' bean cultivar 'Ruda'. Initially, four backcross (BC) lines were obtained using 'TO', 'AB 136', 'Ouro Negro' and 'AND 277' as donor parents. Molecular fingerprinting was used to select the lines genetically closer to the recurrent parent. The relative genetic distances between 'Rudá' and the BC lines varied between $0.0 \%$ and $1.99 \%$. The $\mathrm{BC}$ lines were intercrossed and molecular markers linked to the resistance genes were used to identify the plants containing the genes of interest. These plants were selfed to obtain the $F_{2}, F_{3}$ and $F_{4}$ plants which were selected based on the presence of the molecular markers mentioned and resistance was confirmed in the $\mathrm{F}_{4}$ generation by inoculation. Four $\mathrm{F}_{4: 7}$ pyramid lines with all the resistance genes showed resistance spectra equivalent to those of their respective donor parents. Yield tests showed that these lines are as productive as the best 'carioca-type' cultivars.
\end{abstract}

Key words: Phaseolus vulgaris — disease resistance - gene pyramiding — molecular breeding — marker-assisted selection

In tropical countries the common bean (Phaseolus vulgaris L.) is grown all along the year under different temperatures, light intensities, relative humidities and water availability. These conditions may favour the development of several types of pathogens. Vieira (1983) mentions more than 45 diseases affecting the common bean, incited by fungi, bacteria, viruses and nematodes.

Anthracnose, angular leaf spot and rust are fungal diseases incited by Colletotrichum lindemuthianum (Sacc. \& Magnus) Lams.-Scrib., Pseudocercospora griseola (Sacc.) Crous \& U. Braun, and Uromyces appendiculatus F. Strauss (sin. $U$. phaseoli $\mathrm{G}$. Winter), respectively. They are among the most destructive fungal diseases affecting the common bean in Brazil, and in other tropical and sub-tropical growing regions of the world. In the case of anthracnose and angular leaf spot losses may reach between $70 \%$ and 100\% (Del Peloso 1992 , Jesus Junior et al. 2001). Recommended control measures for these diseases include crop rotation, elimination of contaminated material, as well as the use of fungicides and resistant cultivars (Pastor-Corrales and Schwartz 1994). Chemical products are hardly used in non-irrigated crops due to the need of specific technical knowledge and also because they increase the production costs. Besides, chemical products are often an ecotoxicological concern. The use of resistant cultivars is an efficient, safe and inexpensive alternative accessible to bean growers. In this sense, new disease resistance genes are constantly being characterized and introduced into commercial bean varieties (Kelly and Vallejo 2004, Moreira et al. 2006, Vidigal Filho et al. 2007).

Gene pyramiding, i.e. the combination of several resistance genes in a single cultivar each conferring resistance to a specific race of the same pathogen may yield a medium-to-long-term control (Kelly et al. 1995). A well-succeeded example of this approach in common bean breeding is the use of a gene pyramid with three genes ( $U P-2, B-190$ and $U r-3)$ which confer resistance to 63 out of $65 U$. appendiculatus races tested by the USDA (Kelly et al. 1994). Gene pyramiding was also used to associate five different genes $\left(I, b c-u, b c-1^{2}, b c-2^{2}, b c-3\right)$ in the same cultivar conferring resistance to common bean mosaic virus (Kelly et al. 1995).

However, this strategy is difficult to accomplish by conventional breeding methods because the effect of individual resistance genes cannot be easily identified or measured when they are in the presence of other resistance genes in a specific background. This strategy can be aided by molecular markers that allow the simultaneous monitoring of several resistance genes (Miklas et al. 1993, Kelly et al. 1995). The current status of molecular marker-assisted selection (MAS) for resistance to angular leaf spot, anthracnose, rust, and to several other fungal, bacterial and viral diseases in common bean has been recently reviewed in detail (Miklas et al. 2006).

Molecular markers can also be used to accelerate the recovery of the recurrent parent's genome in backcross breeding programmes (Young and Tanksley 1989, Faleiro et al. 2004). Simulation studies and field data indicate that only three backcrosses are necessary to recover the recurrent parent's genome when molecular markers are used (Openshaw et al. 1994, Faleiro et al. 2004).

In this work, we report the development of advanced 'carioca-type' common bean lines simultaneously resistant to $U$. appendiculatus, C. lindemuthianum and P. griseola. Molecular fingerprinting based on the RAPD-PCR technique was 
used to accelerate the development of the bean lines and molecular MAS was used to combine the different resistance genes in a single genetic background.

\section{Materials and Methods}

Genetic material: Cultivar 'Rudá' was used as the recurrent parent. It is a 'carioca-type' Mesoamerican bean cultivar highly recommended for many growing regions in Brazil but susceptible to rust, anthracnose and angular leaf spot. Cultivars 'Ouro Negro', 'TO', 'AB 136' and 'AND 277 ' were the used as donor parents. 'Ouro Negro' is a black seeded Mesoamerican bean cultivar harbouring the genes $\mathrm{Ur}-\mathrm{ON}$ and $\mathrm{Co}-10$. It is resistant to several races of $U$. appendiculatus (Faleiro et al. 2004) and C. lindemuthianum (Lanza et al. 1997). The other three donor parents, 'TO', 'AB 136' and 'AND 277', are not commercial cultivars in Brazil. 'TO' is a dark beige seeded Mesoamerican bean cultivar harbouring the gene $\mathrm{Co}-4$. It has been shown to be resistant to 22 of 25 C. lindemuthianum races identified in Brazil (Rava et al. 1994). 'AB 136' is a red seeded Mesoamerican bean cultivar harbouring the gene Co-6. It has been shown to be resistant to $25 C$. lindemuthianum races collected in several common bean-growing regions in Brazil (Rava et al. 1994, Alzate-Marin et al. 1999a, 2000). 'AND 277' is an Andean bean cultivar which belongs to the 'Manteigão' group and harbours the gene $P h g-l$ that confers an effective protection against the most virulent races of $P$. griseola identified in Brazil (Nietsche et al. 2000).

Crosses: The crosses between 'Ruda' and the donor parents were conducted in the greenhouse. Four separate backcross programmes were conducted until $\mathrm{BC}_{3}$ or $\mathrm{BC}_{4}\left(\mathrm{BC}_{\mathrm{n}}\right)$ generations using 'Rudá' as recurrent parent and cultivars 'TO', 'AB 136', 'Ouro Negro' or 'AND $277^{\prime}$ as donor parents. After each backcross (BC) the plants were screened with molecular markers linked to the genes of interest. The genetic distances between the selected plants and the recurrent parent were determined with RAPD markers and the ones closest to 'Rudá' were used for the next $\mathrm{BC}$ cycle. The $\mathrm{BC}_{\mathrm{n}} \mathrm{F}_{2}$ plants were selfed to obtain $\mathrm{BC}_{\mathrm{n}} \mathrm{F}_{2: 3}$ which were submitted to progeny tests based on inoculations of the three pathogens to obtain homozygous resistant lines. Colletotrichum lindemuthianum race 65 was used to inoculate lines from the cross 'Rudá' $v s$. 'TO', and race 89 was used to inoculate lines from the crosses 'Rudá' vs. 'Ouro Negro' and 'Rudá' vs. 'AB 136'. Pseudocercospora griseola race 63.23 was used to inoculate the lines from the cross 'Rudá' vs. 'AND 277'. A mixture of spores of $U$. appendiculatus (Table 4) was used to inoculate the lines from the cross 'Rudá' vs. 'Ouro Negro'. Among the resistant lines the ones genetically closest to 'Rudá', based on molecular fingerprinting and yield tests, were selected for the pyramiding process. This process consisted of two steps: step 1-pairwise crosses among the $\mathrm{BC}_{\mathrm{n}} \mathrm{F}_{2: 3^{-}}$ resistant lines to obtain single-hybrids; step 2-intercrossing of the single-hybrids to obtain the double-hybrids with all the resistance genes of interest. The double-hybrid plants were screened with molecular markers linked to the disease resistance genes of interest (Table 1). The plants harbouring all the markers were selfed to obtain the subsequent generations. The $\mathrm{F}_{2}, \mathrm{~F}_{3}$ and $\mathrm{F}_{4}$ plants derived from the double-hybrids were also selected with the molecular markers. $F_{4: 5}$ seeds from $\mathrm{F}_{4}$ plants containing all the markers associated with the resistance genes were used for progeny tests to identify homozygous families for resistance to anthracnose (C. lindemuthianum race 65 ), rust (mixture of the $U$. appendiculatus races described in Table 4) and angular leaf spot (P. griseola race 63-23). $\mathrm{F}_{4: 6}$ seeds from the selected homyzogous families were sowed in the field for yield determination and selection of the best-yielding families. The best-yielding $\mathrm{F}_{4: 7}$ families (pyramid lines) were evaluated for yield components and for resistance to the three pathogens of interest using a larger number of races.

Inoculation of pathogens and evaluation of symptoms: The inoculation procedure with $U$. appendiculatus was carried out according to Faleiro et al. (1999). Six grades of rust reaction were considered in the evaluation of the disease symptoms based on the scale proposed by Stavely et al. (1983), where $1=$ no symptoms; $2=$ necrotic flecks or spots without uredinia; $3=$ uredinia less than $300 \mu \mathrm{m}$ in diameter; $4=$ uredinia $300-499 \mu \mathrm{m}$ in diameter; $5=$ uredinia $500-799 \mu \mathrm{m}$ in diameter; and $6=$ uredinia $800 \mu \mathrm{m}$ in diameter or larger. The methodology described by Lanza et al. (1997) was used for C. lindemuthianum inoculation and the anthracnose symptoms were evaluated by a 9-grade scale of reactions proposed by Pastor-Corrales (1992), where 1 = plants with no visible symptoms; 2 = few isolated small lesions on mid-veins in the lower leaf surface; $3=$ more frequency of small lesions on midveins in the lower leaf surface; $4=$ lesions present in the mid-vein and occasionally in secondary leaf veins; $5=$ many small lesions scattered on mid- and secondary veins; $6=$ many small lesions as described in grade 5 in the lower and upper leaf surface and in the stems and petioles; $7=$ large lesions scattered over the leaf blade and many lesions in the stems and petioles; $8=$ many large coalesced lesions accompanied by tissue breakdown and chlorotic or abscised leaflets, reduced plant growth, and many lesions in stems and petioles; and $9=$ severely diseased or dead plants. For the diagnosis of the reactions incited by the fungus $P$. griseola, the first trifoliate leaf of the plants was inoculated (Nietsche et al. 2000). Angular leaf spot was evaluated by a 1-9 scale based on Van-Schoonhoven and PastorCorrales (1987) where $1=$ no symptoms; 2 = lesions on up to $3 \%$ of leaf area; $3=$ lesions on up to $5 \%$ of leaf area, with no sporulation of the pathogen; $4=$ lesions and sporulation on up to $10 \%$ of leaf area; $5=$ lesions and sporulations with $2-3 \mathrm{~mm}$ in diameter on $10-15 \%$ of

Table 1: RAPD and SCAR molecular markers linked to resistance genes to Uromyces appendiculatus (Ur), Colletotrichum lindemuthianum (Co) and Pseudocercospora griseola (Phg)

\begin{tabular}{|c|c|c|c|c|c|c|}
\hline Marker & $\begin{array}{l}\text { Primer sequence } \\
\qquad\left(5^{\prime} \rightarrow 3^{\prime}\right)\end{array}$ & $\begin{array}{l}\text { Distance } \\
(\mathrm{cM})\end{array}$ & $\mathrm{LG}^{1}$ & $\begin{array}{l}\text { Resistance } \\
\text { gene }\end{array}$ & $\begin{array}{l}\text { Resistance } \\
\text { source }\end{array}$ & Reference \\
\hline $\mathrm{OPH}_{13} 3_{490}$ & GACGCCACAC & 5.5 & -2 & Phg-1 & AND 277 & Carvalho et al. (1998) \\
\hline $\mathrm{OC}_{900}$ & TGGACCGGTG & 9.7 & B8 & $\mathrm{Co}-4$ & TO & Alzate-Marin et al. (1999a) \\
\hline $\mathrm{OB} 3_{1800}$ & САТСССССТG & 3.7 & B8 & Co-4 & TO & Alzate-Marin et al. (1999a) \\
\hline $\mathrm{OAZ}_{560}$ & CCAGCCTCAG & 8.5 & B7 & Co-6 & AB 136 & Alzate-Marin et al. (1999b) \\
\hline $\mathrm{OX} 11_{550}$ & GGAGCCTCAG & 5.8 & B4 & $\mathrm{Ur}-\mathrm{ON} / \mathrm{Co}-10$ & Ouro Negro & Faleiro et al. (2000) \\
\hline SCARY $20_{830}$ & $\begin{array}{l}\text { F: AGCCGTGGAAGGTTGTCAT } \\
\text { R: CCGTGGAAACAACACACAAT }\end{array}$ & 1.2 & B8 & $\mathrm{Co}-4$ & TO & Queiroz et al. (2004a) \\
\hline SCARAZ20 940 & $\begin{array}{l}\text { F: ACCCCTCATGCAGGTTTTTA } \\
\text { R: CATAATCCATTCATGCTCACC }\end{array}$ & 7.1 & B7 & Co-6 & AB 136 & Queiroz et al. (2004a) \\
\hline SCARF $10_{1050}$ & $\begin{array}{l}\text { F: GGAAGCTTGGTGAGCAAGGA } \\
\text { R: GGAAGCTTGGCTATGATGGT }\end{array}$ & 7.0 & B4 & $\mathrm{Ur}-\mathrm{ON} / \mathrm{Co}-10$ & Ouro Negro & Corrêa et al. (2000) \\
\hline $\mathrm{SCARH}_{13} 3_{490}$ & $\begin{array}{l}\text { F: GACGCCACACCCATTATGTT } \\
\text { R: GCCACACAGATGGAGCTTTA }\end{array}$ & 5.6 & - & Phg-1 & AND 277 & Queiroz et al. (2004b) \\
\hline
\end{tabular}

F, forward; R, reverse.

${ }^{1}$ Linkage group where the marker is located in the bean core map (Kelly et al. 2003).

${ }^{2}$ Not available. 
leaf area; $6=$ lesions and sporulations $>3 \mathrm{~mm}$ in diameter on $15-20 \%$ of leaf area; $7=$ lesions and sporulations $>3 \mathrm{~mm}$ in diameter on $20-25 \%$ of leaf area; $8=$ lesions and sporulations $>3 \mathrm{~mm}$ in diameter on $25-30 \%$ of leaf area; and $9=$ lesions, frequently associated with early loss of leaves and plant death, on $90 \%$ of leaf area.

Reaction grades to the three pathogens were determined by visual observation of the lesions on the inoculated leaves. Because of the approach we used in which resistance genes (major genes) were tagged with molecular markers which were then used for assisted selection, the plants were divided into two groups: resistant and susceptible. Plants with grades 1-3 were considered resistant and those with grades 4 or higher were considered to be susceptible. These cut-off values were also used by other bean researchers working with MAS (Mahuku et al. 2004, Park et al. 2004, Garzón et al. 2008).

Molecular marker analysis: Leaf DNA was extracted according to Doyle and Doyle (1990). In each BC a screening was done to identify polymorphic RAPD primers (Operon Technologies, Alameda, CA, USA) for use in the molecular fingerprinting assays of the nonsegregating $\mathrm{BC}_{\mathrm{n}} \mathrm{F}_{2: 3}$ lines (Table 2). These primers revealed at least one polymorphic DNA band among the plants analysed. The DNA amplification by RAPD technique and the electrophoresis in agarose gel procedure were according to Faleiro et al. (2000). The polymorphic and monomorphic DNA bands were used to build a matrix based on the presence (1) or absence (0) of DNA bands. The genetic distances were calculated by the Euclidian method for binary data and used to cluster the plants by the nearest neighbour method with the aid of the program SYSTAT for Windows, version 5 (Wilkinson et al. 1992).

For the molecular MAS of the double-hybrid, $\mathrm{F}_{2}, \mathrm{~F}_{3}$ and $\mathrm{F}_{4}$ plants, RAPD and SCAR markers linked to each one of the resistance genes were used (Table 1). In the assays with the SCAR technique, the procedures were similar to those in the trials with RAPDs, except that the primer was replaced by $0.2 \mu \mathrm{M}$ of each specific primer. The temperatures of specific annealing for each SCAR primer are described in the references in Table 1.

Analysis of yield components: Yield components of the BC lines were evaluated at the Federal University of Viçosa Experimental Station (Coimbra, MG, Brazil) in two distinct growing seasons (autumn and spring of 2000). They included four resistant $\mathrm{BC}_{\mathrm{n}} \mathrm{F}_{2: 3}$ lines, and four reference cultivars: 'Rudá', 'Ouro Negro', 'Pérola' and 'Aporé'. 'Ouro Negro' is a black seeded cultivar and the other three are 'carioca-type' cultivars. The four references are high-yielding commercial cultivars widely planted in Brazil.

To evaluate the pyramid lines, two field experiments were conducted, one in the spring of 2003 and the other in the autumn of 2004.

\begin{tabular}{lcccc}
\hline & \multicolumn{4}{c}{ Resistance source } \\
\cline { 2 - 5 } Characteristic/parameter & Ouro Negro & $\mathrm{TO}$ & $\mathrm{AB} 136$ & AND 277 \\
\hline Generation & $\mathrm{BC}_{3} \mathrm{~F}_{2: 3}$ & $\mathrm{BC}_{4} \mathrm{~F}_{2: 3}$ & $\mathrm{BC}_{4} \mathrm{~F}_{2: 3}$ & $\mathrm{BC}_{4} \mathrm{~F}_{2: 3}$ \\
Resistance gene(s) & $U r-O N / C O-10$ & $C o-4$ & $C o-6$ & $P h g-1$ \\
Proportion of resistant & $13 / 47$ & $15 / 25$ & $6 / 21$ & $5 / 18$ \\
$\quad$ non-segregating BC lines & & & & 42 \\
Number of RAPD primers & 26 & 27 & 336 & 383 \\
Total number of DNA bands & 226 & 51 & 40 & 153 \\
Number of polymorphic bands & 51 & $0.56-1.97$ & $0.52-1.04$ & $0.22-1.99$ \\
Genetic distance range (\%) & $0.00-1.50$ & &
\end{tabular}

Table 2: Characteristics of the backcross (BC) lines, parameters used for their molecular fingerprinting analysis and evaluation of relative genetic distances between the recurrent genitor 'Rudá' and the selected BC lines

${ }^{1}$ Number of homozygous resistant $\mathrm{BC}$ lines divided by the number of lines tested in the progeny tests.


Fig. 1: Diagram representing the breeding strategy used to develop 'carioca-type' common bean lines backcross (BC) lines] in four separate $\mathrm{BC}$ programmes 
In the first experiment only grain production was evaluated. It included 40 resistant $\mathrm{F}_{4: 6}$ lines and four reference cultivars: 'Rudá, 'Ouro Negro', 'Pérola' and 'Aporé'. In the second experiment yield components of the four best yielding lines of the first experiment and three 'carioca-type' reference cultivars ('Rudá', 'Pérola' and 'Talismã') were evaluated.

In all experiments a randomized complete block design with three repetitions (plots) was used. Each plot consisted of two rows each $2.0 \mathrm{~m}$ long, spaced by $0.5 \mathrm{~m}$, with 17 seeds per meter. The equivalent of $600 \mathrm{~kg} / \mathrm{ha}$ of the formula 4-14-8 $\left(\mathrm{N}, \mathrm{P}_{2} \mathrm{O}_{5}\right.$ and $\mathrm{K}_{2} \mathrm{O}$, respectively) was used as fertilizer during sowing, and $200 \mathrm{~kg} / \mathrm{ha}$ ammonium sulphate was applied 20 days after emergence. The whole plot was harvested manually. The yield components evaluated were: grain yield (GY), determined for each plot and expressed as $\mathrm{kg} / \mathrm{ha}$; plant height (PLH), the mean height (in centimetres) of the plants at stage R8 in each plot; mean number of seeds per pod (SEP) in each plot; mean number of pods per plant (POP) in each plot. The Tukey test was used to evaluate the significance of the differences among the mean values obtained for each trait.

\section{Results}

Backcrosses and gene pyramiding aided by molecular markers

The relative genetic distances between recurrent genitor 'Rudá' and the resistant $\mathrm{BC}$ lines (ON-48-99, AB-74-1-18, TO-41-5-624 and $\mathrm{AN}-7-2-9-7-10)$ derived from the separate BC programmes from cultivars 'Ouro Negro', 'TO', 'AB 136' and 'AND 277', respectively, varied between $0.0 \%$ and $1.99 \%$. The number of polymorphic DNA bands used to calculate the genetic distances varied between 40 and 153 (Table 2).

The BC lines which were genetically closest to 'Rudá' were crossed pairwise to start the pyramiding process of resistance genes to anthracnose, rust and angular leaf spot in the 'carioca' background 'Rudá'. The $F_{1}$ plants obtained were intercrossed to obtain double-hybrids. The double-hybrid plants that presented all molecular markers were selfed and $235 \mathrm{~F}_{2}$ seeds were obtained. DNA obtained from the $F_{2}$ plants was amplified with the molecular markers and 13 plants were

BC Lines



Fig. 2: Diagram representing the breeding strategy used to develop 'carioca-type' common bean lines (pyramid lines) simultaneously resistant to anthracnose, angular leaf spot and rust yramid lines: with "carioca-type" grains and homozygous for all resistance loc four best best yielding families with the three pathogens 
selected. These plants were selfed to obtain the subsequent generations. For the selection of plants carrying all disease resistance genes in subsequent generations, the presence of RAPD and SCAR markers was used as selection criterion (Figs 1 and 2).

Four hundred and thirty $\mathrm{F}_{3}$ plants were obtained. To reduce the number of plants to be genotyped by molecular markers, the $\mathrm{F}_{3}$ plants were inoculated with $P$. griseola race 63-23. Two hundred and thirty plants were resistant and genotyped with the molecular markers; five of them harboured all the markers. One hundred and fifty-six $\mathrm{F}_{4}$ seeds were obtained and sowed. The corresponding $\mathrm{F}_{4}$ plants were analysed with the molecular markers and the ones containing all markers were used for progeny tests. $\mathrm{F}_{4: 5}$ families were inoculated with races of $U$. appendiculatus, $C$. lindemuthianum and $P$. griseola to select those that were homozygous for the resistance genes. Following this methodology it was possible to obtain $40 \mathrm{~F}_{4: 5}$ families phenotypic and genotypically similar to the recurrent cultivar 'Rudá' and possessing the resistance genes $\mathrm{Ur}-\mathrm{ON}, \mathrm{Co}-4, \mathrm{Co}-6$, Co-10 and Phg- 1 (Figs 1 and 2).

\section{Yield evaluation}

The four selected BC lines from which the pyramid lines were derived were tested for quantitative traits related to yield (autumn and spring of 2000). The BC lines performances were very similar to those of the recurrent parent 'Ruda' and to the other reference cultivars. Only line AN-7-2-9-7-10 differed statistically in relation to 'Rudá' with respect to three of the four yield components analysed (Table 3).

The $40 \mathrm{~F}_{4: 5}$ families selected in the progeny test were multiplied in the field to obtain enough seeds for evaluation of

Table 3: Agronomic performance of backcross (BC) lines (autumn and spring, 2000) and pyramid lines (autumn, 2004), Coimbra, MG, Brazil

\begin{tabular}{lcccc}
\hline & \multicolumn{4}{c}{ Yield component } \\
\cline { 2 - 5 } BC line or cultivar & $\mathrm{GY}^{1}$ & PLH $^{2}$ & SEP $^{3}$ & POP $^{4}$ \\
\hline ON-48-99 & $2510.84 \mathrm{~b}$ & $53.62 \mathrm{~b}$ & $4.73 \mathrm{a}$ & $15.70 \mathrm{a}$ \\
TO-41-5-6-24 & $2933.13 \mathrm{ab}$ & $57.62 \mathrm{~b}$ & $4.90 \mathrm{a}$ & $16.78 \mathrm{a}$ \\
AB-74-1-18 & $3422.26 \mathrm{a}$ & $55.12 \mathrm{~b}$ & $4.95 \mathrm{a}$ & $17.18 \mathrm{a}$ \\
AN-7-2-9-7-10 & $1581.54 \mathrm{c}$ & $30.12 \mathrm{c}$ & $3.43 \mathrm{~b}$ & $13.28 \mathrm{a}$ \\
Rudá & $2638.08 \mathrm{ab}$ & $53.37 \mathrm{~b}$ & $5.14 \mathrm{a}$ & $14.95 \mathrm{a}$ \\
Ouro Negro & $2925.39 \mathrm{ab}$ & $54.50 \mathrm{~b}$ & $5.04 \mathrm{a}$ & $15.78 \mathrm{a}$ \\
Pérola & $2546.00 \mathrm{~b}$ & $73.75 \mathrm{a}$ & $5.18 \mathrm{a}$ & $16.13 \mathrm{a}$ \\
Aporé & $2621.67 \mathrm{ab}$ & $46.50 \mathrm{~b}$ & $4.77 \mathrm{a}$ & $17.98 \mathrm{a}$ \\
Mean & 2647.36 & 53.07 & 4.78 & 15.97 \\
CV (\%) & 14.07 & 10.01 & 4.48 & 13.47 \\
\hline Pyramid line or cultivar & GY & PLH & SEP & POP \\
\hline R-127-10-14 & $2064.26 \mathrm{a}$ & $43.33 \mathrm{a}$ & $5.52 \mathrm{a}$ & $6.45 \mathrm{ab}$ \\
R-97-13-5 & $2064.28 \mathrm{a}$ & $43.33 \mathrm{a}$ & $5.19 \mathrm{a}$ & $5.92 \mathrm{~b}$ \\
R-97-13-6 & $2150.30 \mathrm{a}$ & $44.33 \mathrm{a}$ & $4.07 \mathrm{a}$ & $8.91 \mathrm{a}$ \\
R-127-4-13 & $2084.38 \mathrm{a}$ & $44.66 \mathrm{a}$ & $4.71 \mathrm{a}$ & $7.64 \mathrm{ab}$ \\
Talismã & $1923.30 \mathrm{a}$ & $40.33 \mathrm{a}$ & $4.30 \mathrm{a}$ & $7.21 \mathrm{ab}$ \\
Pérola & $1914.91 \mathrm{a}$ & $44.66 \mathrm{a}$ & $4.39 \mathrm{a}$ & $6.51 \mathrm{ab}$ \\
Rudá & $1631.43 \mathrm{a}$ & $42.33 \mathrm{a}$ & $4.08 \mathrm{a}$ & $7.47 \mathrm{ab}$ \\
Mean & 1976.13 & 43.28 & 4.61 & 7.51 \\
CV (\%) & 9.53 & 7.59 & 12.52 & 12.40 \\
\hline
\end{tabular}

Means followed by the same letter in the column do not differ by the Tukey test at $5 \%$ probability.

${ }^{1}$ Grain yield in $\mathrm{kg} /$ ha $(\mathrm{GY})$

${ }^{2}$ Plant height in $\mathrm{cm}$ at stage $\mathrm{R} 8(\mathrm{PLH})$

${ }^{3}$ Number of seeds per pod (SEP).

${ }^{4}$ Number of pods per plant (POP). agronomic traits. The corresponding $\mathrm{F}_{4: 6}$ families were tested for grain yield during the spring of 2003. The $F$-statistic $\left(\mathrm{P}<0.01, R^{2}=37.5 \%\right)$ indicated that there was genetic variability for grain yield among the 40 families analysed (data not shown). The four best yielding families (R-127-10-14, R97-13-5, R-97-13-6 and R-127-4-13) were evaluated for yield components during the autumn of 2004. The mean values for the yield components of the $\mathrm{F}_{4: 7}$ families (pyramid lines) did not differ statistically in relation to 'Rudá' and the other reference cultivars (Table 3 ).

\section{Resistance evaluation}

The four BC lines (ON-48-99, AB-74-1-18, TO-41-5-6-24 and AN-7-2-9-7-10) derived from the separate BC programmes, and the corresponding genitor cultivars were tested against 10 $U$. appendiculatus, $15 C$. lindemuthianum and seven $P$. griseola races. Cultivar 'Ouro Negro' and line ON-48-99 were resistant to all $U$. appendiculatus and to 13 of the C. lindemuthianum races tested. 'TO', 'AB 136' and lines AB-74-1-18 and TO-41-56-24 were resistant to all $15 \mathrm{C}$. lindemuthianum races tested. 'AND 277' was resistant to six and line AN-7-2-9-7-10 to five of the seven $P$. griseola races tested (Table 4).

The four selected $\mathrm{F}_{4: 7}$ pyramid lines (R-127-10-14, R-97-135, R-97-13-6 and R-127-4-13) were tested against 10 U. appendiculatus, $15 C$. lindemuthianum and seven $P$. griseola races. These four lines were resistant to all $U$. appendiculatus and $C$. lindemuthianum races tested. Their resistance spectra correspond to those of the donor parents (Table 4). In the case of angular leaf spot the lines were resistant to five of the seven $P$. griseola races tested.

\section{Discussion}

After yield, disease resistance is the main focus of common bean breeders throughout the world. In fact, the large number of pathogens affecting this crop is one of the main causes of the low yield observed in many bean-growing regions (PastorCorrales and Schwartz 1994). In this work we report the development of 'carioca-type' common bean lines simultaneously carrying genes conferring resistance to several races of C. lindemuthianum (Co-4, Co-6 and Co-10), U. appendiculatus $(U r-O N)$ and P. griseola (Phg-1). The concept of gene pyramiding assisted by molecular markers has been successfully used to create advanced lines with wide and potentially durable resistance. Resistance genes (major genes) were tagged with molecular markers which were then used to monitor the introgression of the genes into a specific 'carioca-type' background. Although a gene pyramid was built which is not easily overcome, minor genes were not specifically selected and might have been lost during the breeding process. This potential loss was minimized by the use of inoculations during the final steps of the breeding procedure. The use of four separate BC programmes assisted by molecular marker fingerprinting allowed the individual introgression of the resistance genes in cultivar 'Rudá' after only three or four BC cycles. In addition, this strategy also allowed the identification and validation of specific molecular markers during the breeding process (references in Table 1). These markers were effectively used to aid the pyramiding process and the development of advanced lines simultaneously resistant to rust, anthracnose and angular leaf spot. The efficiency of the markers was confirmed by inoculation with the causal agents of the three diseases. The 





advanced lines obtained showed the same resistance spectra present in the donor parents for anthracnose and rust resistance (Table 4). In the case of angular leaf spot, unlike the donor parent 'AND 277' resistance to race 31.39 was not present in the advanced lines (Table 4). In fact, the BC line AN-7-2-9-7-10 which derived the advanced pyramid lines was also susceptible to that $P$. griseola race (Table 4). The marker used during the pyramiding process was linked to gene Phg-l which confers resistance to $P$. griseola race 63-23 (Carvalho et al. 1998); however, it is known that 'AND 277' possesses at least three other angular leaf spot resistance genes (Caixeta et al. 2005). These genes, or part of them, might have been lost during the $\mathrm{BC}$ process once they were not being selected with the molecular marker used. Evaluation of yield components of the advanced lines demonstrates that no yield penalty in relation to cultivar 'Rudá' was observed after the pyramiding process (Table 3 ).

The lines developed are now being evaluated in different bean-growing regions by a Brazilian Bean Assay Network for productivity and disease resistance. If the superior agronomic performance of these lines is confirmed they will be recommended as new cultivars. In addition, the resistance gene pyramids can be transferred to other 'carioca-type' cultivars or to other bean types which are also consumed in Brazil. In this sense, our group has been actively working to transfer the resistance genes to other 'carioca-type' cultivars (Pérola and Talismã), and also to cultivars belonging to other groups such as cv. 'Diamante Negro' (black bean) and cv. 'Ouro Vermelho' (red bean). In addition, new resistance sources are being tested and added to our breeding programme to widen the basis of the present gene pyramids. In the case of rust, new resistance sources (Belmidak RR-3 and Mexico 309) have already been characterized and added to the breeding programme (Souza et al. 2005). New resistance sources for angular leaf spot (MAR-2, Mexico 54, BAT 332 and Cornell 49-242) have also been added to the breeding programme (Sanglard et al. 2007). As for anthracnose, the Co-4 allele from cv. 'TO' has been replaced by the $\mathrm{Co}-4^{2}$ allele from cv. 'G 2333'. This allele is the only one characterized so far that can overcome C. lindemuthianum race 2047 (Alzate-Marin et al. 2004).

To be effective, the gene pyramiding strategy must be a continuous effort. Permanent monitoring for the presence of new virulent races in the field and search for new resistance sources are inherent steps in this breeding strategy.

\section{Acknowledgements}

This work was supported by grants from CNPq and FAPEMIG (Brazilian government). CNPq provided fellowships to V. A. Ragagnin, T. L. P. O. de Souza, D. A. Sanglard, K. M. A. Arruda and M. R. Costa.

\section{References}

Alzate-Marin, A. L., M. C. C. Arruda, H. Menarim, J. M. Chagas, E. G. Barros, and M. A. Moreira, 1999a: Identification of RAPD markers linked to resistance genes to anthracnose in common bean cultivars AB136, TO and G2333. Annu. Rep. Bean Improv. Coop. 42, $13-14$

Alzate-Marin, A. L., H. Menarim, G. A. Carvalho, T. J. Paula-Júnior, E. G. Barros, and M. A. Moreira, 1999b: Improved selection with newly identified RAPD markers linked to resistance gene to four pathotypes of Colletotrichum lindemuthianum in common bean. Phytopathology 89, 281-285.
Alzate-Marin, A. L., H. Menarim, J. M. Chagas, E. G. Barros, and M. A. Moreira, 2000: Identification of a RAPD marker linked to the Co-6 anthracnose resistance gene in common bean cultivar AB 136 Gen. Mol. Biol. 23, 633-637.

Alzate-Marin, A. L., K. M. Arruda, K. A. Souza, E. G. Barros, and M. A. Moreira, 2004: Introgression of $\mathrm{Co}-4^{2}$ and $\mathrm{Co}-5$ anthracnose resistance genes into 'carioca' common bean cultivars. Crop Breed. Appl. Biotechnol. 4, 446-451.

Caixeta, E. T., A. Borém, A. L. Alzate-Marin, A. S. Fagundes, M. G M. Silva, E. G. Barros, and M. A. Moreira, 2005: Allelic relationships for genes that confer resistance to angular leaf spot in common bean. Euphytica 143, 237-245.

Carvalho, G. A., T. J. Paula Jr, A. L. Alzate-Marin, S. Nietsche, E. G. Barros, and M. A. Moreira, 1998: Herança da resistência da linhagem AND 277 de feijoeiro-comum à raça 63-23 de Phaeoisariopsis griseola e identificação de marcador RAPD ligado ao gene de resistência. Fitopatol. Bras. 23, 482-485.

Corrêa, R. X., M. R. Costa, P. I. Good-God, V. A. Ragagnin, F. G. Faleiro, W. S. Vinhadelli, M. A. Moreira, and E. G. Barros, 2000: Sequence characterized amplified regions linked to rust resistance genes in the common bean. Crop Sci. 40, 804-807.

Del Peloso, M. J., 1992: Antracnose do feijoeiro no estado de Minas Gerais-Brasil. In: M. A. Pastor-Corrales (ed.), La Antracnosis del Frijol Común (Phaseolus vulgaris) en la America Latina, 86-108. Doc. de Trabajo No. 113, CIAT, Cali.

Doyle, J. J., and J. L. Doyle, 1990: Isolation of plant DNA from fresh tissue. Focus 12, 13-15.

Faleiro, F. G., L. Zambolim, W. S. Vinhadelli, V. A. Ragagnin, T. J. Paula-Júnior, M. A. Moreira, and E. G. Barros, 1999: Sistema simplificado para nomenclatura e classificação de raças fisiológicas de Uromyces appendiculatus. Fitopatol. Bras. 24, 540-545.

Faleiro, F. G., W. S. Vinhadelli, V. A. Ragagnin, R. X. Corrêa, M. A. Moreira, and E. G. Barros, 2000: RAPD markers linked to a block of genes conferring rust resistance to the common bean. Genet. Mol. Biol. 23, 399-402.

Faleiro, F. G., V. A. Ragagnin, M. A. Moreira, and E. G. Barros, 2004: Use of molecular markers to accelerate the breeding of common bean lines resistant to rust and anthracnose. Euphytica 138, $213-218$.

Garzón, L. N., G. A. Ligarreto, and M. W. Blair, 2008: Molecular marker-assisted backcrossing of anthracnose resistance into andean climbing beans (Phaseolus vulgaris L.). Crop Sci. 48, $562-570$.

Jesus Junior, W. C., F. X. R. do Vale, R. R. Coelho, B. Hau, L. Zambolim, L. C. Costa, and A. Bergamin Filho, 2001: Effects of angular leaf spot and rust on yield losses of Phaseolus vulgaris. Phytopathology 91, 1045-1053.

Kelly, J. D., and V. A. Vallejo, 2004: A comprehensive review of the major genes conditioning resistance to anthracnose in common bean. HortScience 39, 1196-1207.

Kelly, J. D., S. D. Haley, L. Afanador, P. N. Miklas, and J. R. Stavely, 1994: Application of RAPD markers for disease resistance breeding in beans. Annu. Rep. Bean Improv. Coop. 37, 15-16.

Kelly, J. D., L. Afanador, and S. S. Haley, 1995: Pyramiding genes for resistance to bean common mosaic virus. Euphytica 82, $207-212$.

Kelly, J. D., P. Gepts, P. N. Miklas, and D. P. Coyne, 2003: Tagging and mapping of genes and QTL and molecular marker-assisted selection for traits of economic importance in bean and cowpea. Field Crops Res. 82, 135-154.

Lanza, M. A., T. J. Paula-Júnior, W. S. Vinhadelli, M. A. B. Morandi, E. G. Barros, and M. A. Moreira, 1997: Resistência à antracnose em cultivares de feijoeiro-comum recomendadas para Minas Gerais. Fitopatol. Bras. 22, 560-562.

Mahuku, G., C. Montoya, M. A. Henriquez, C. Jara, H. Teran, and S. Beebe, 2004: Inheritance and characterization of angular leaf spot resistance gene present in common bean accession G 10474 and identification of an AFLP marker linked to the resistance gene. Crop Sci. 44, 1817-1824. 
Miklas, P. N., J. R. Stavely, and J. D. Kelly, 1993: Identification and potential use of a molecular marker for rust resistance in common bean. Theor. Appl. Genet. 85, 745-749.

Miklas, P. N., J. D. Kelly, S. E. Beebe, and M. W. Blair, 2006: Common bean breeding for resistance against biotic and abiotic stresses: from classical to MAS breeding. Euphytica 147, $105-131$.

Moreira, M. A., E. G. Barros, J. E. S. Carneiro, F. G. Faleiro, L. C. Faria, G. E. S. Carneiro, M. J. Del Peloso, T. J. Paula Jr, A. F. B. Abreu, M. A. P. Ramalho, L. C. Melo, J. B. Santos, C. A. Rava, J. G. C. Costa, A. Sartorato, and J. C. Faria, 2006: BRSMG Pioneiro: new carioca common bean cultivar resistant to anthracnose and rust, for the Southern of Brazil. Annu. Rep. Bean Improv. Coop. 49, 279-280.

Nietsche, S., A. Borém, G. A. Carvalho, R. C. Rocha, T. J. PaulaJúnior, E. G. Barros, and M. A. Moreira, 2000: RAPD and SCAR markers linked to a gene conferring resistance to angular leaf spot in common bean. J. Phytopathol. 148, 117-121.

Nietsche, S., A. Borém, G. A. Carvalho, T. J. Paula-Júnior, C. F. Ferreira, E. G. Barros, and M. A. Moreira, 2001: Genetic diversity of Phaeoisariopsis griseola in the state of Minas Gerais, Brazil. Euphytica 117, 77-84.

Openshaw, S. J., S. G. Jarboe, and W. D. Beavis, 1994: Markerassisted selection in backcross breeding. In: R. Lower (ed.), ASHS/ CSSA Joint Plant Breeding Symposium on Analysis of Molecular Marker Data, 41-43. Oregon State University, Corvallis, OR.

Park, S. O., D. P. Coyne, J. R. Steadman, K. M. Crosby, and M. A Brick, 2004: RAPD and SCAR markers linked to the $U r-6$ andean gene controlling specific rust resistance in common bean. Crop Sci. 44, 1799-1807.

Pastor-Corrales, M. A., 1992: Variación patogenica de Colletotrichum lindemuthianum, el agente causal de la antracnosis del frijol y una propuesta para su estandatización. In: M. A. Pastor-Corrales (ed.), La Antracnosis del Frijol Común (Phaseolus vulgaris) en la America Latina, 212-239. Doc. de Trabajo No. 113, CIAT, Cali.

Pastor-Corrales, M. A., and H. F. Schwartz, 1994: Problemas de producción del frijol en los tropicos. CIAT, Cali, Colombia.
Queiroz, V. T., C. S. Sousa, M. R. Costa, D. A. Sanglard, K. M. A. Arruda, T. L. P. O. Souza, V. A. Ragagnin, E. G. Barros, and M. A. Moreira, 2004a: Development of SCAR markers linked to common bean anthracnose resistance genes Co-4 and Co-6. Annu. Rep. Bean Improv. Coop. 47, 249-250.

Queiroz, V. T., C. S. Sousa, M. R. Costa, D. A. Sanglard, K. M. A. Arruda, T. L. P. O. Souza, V. A. Ragagnin, E. G. Barros, and M. A. Moreira, 2004b: Development of SCAR markers linked to common bean angular leaf spot resistance genes. Annu. Rep. Bean Improv. Coop. 47, 237-238.

Rava, C., A. Purchio, and A. Sartorato, 1994: Caracterização de patótipos de Colletotrichum lindemuthianum que ocorrem em algumas regiões produtoras de feijoeiro-comum. Fitopatol. Bras. 19, $167-172$.

Sanglard, D. A., J. D. Damasceno, B. P. Balbi, E. G. Barros, and M. A. Moreira, 2007: Introgression of angular leaf spot resistance genes in common bean isolines. Annu. Rep. Bean Improv. Coop. 50, 101-102.

Souza, T. L. P. O., D. A. Sanglard, V. A. Ragagnin, A. L. AlzateMarin, M. A. Moreira, and E. G. Barros, 2005: Development of "carioca-type" common bean lines resistant to rust with the aid of molecular markers. Annu. Rep. Bean Improv. Coop. 48, 138-139.

Stavely, J. R., G. F. Freytag, J. R. Steadman, and H. F. Schwartz, 1983: The 1983 Bean Rust Workshop. Annu. Rep. Bean Improv. Coop. 26, iv-vi.

Van-Schoonhoven, A., and M. A. Pastor-Corrales, 1987: Standard System for Evaluation of Bean Germplasm. CIAT, Cali, Colombia.

Vidigal Filho, P. S., M. C. Gonçalves-Vidigal, J. D. Kelly, and W. W. Kirk, 2007: Sources of resistance to anthracnose in traditional common bean cultivars from Paraná, Brazil. J. Phytopathol. 155, $108-113$.

Vieira, C., 1983: Doenças e pragas do feijoeiro. UFV Press, Viçosa, Minas Gerais, Brazil.

Wilkinson, L., M. Hill, and J. P. Welna, 1992: Statistics. Systat, Chicago.

Young, N. D., and S. D. Tanksley, 1989: Restriction fragment length polymorphism maps and the concept of graphical genotypes. Theor. Appl. Genet. 77, 95-101. 